\title{
How blood reveals us, divides us and unites us
}

\author{
Blood: The Stuff of Life \\ Lawrence Hill \\ House of Anansi Press; 2013
}

$\mathrm{W}$ earing the requisite scrubs and waterproof shoes, I was setting up for the delivery at the foot of my patient's bed. I unwrapped the tray and sorted through my clamps, pans, scissors and needle driver.

"You look like Dexter," my patient said. Her husband chuckled. I'd never seen the show, but I knew she was referring to the serial dramedy depicting the exploits of a friendly neighbourhood serial killer. I chuckled awkwardly, caught the baby girl and handed her to her mother.

I recalled this bizarre conversation as I was reading Lawrence Hill's Blood: The Stuff of Life, the published compilation of the Massey Lecture series Hill delivered earlier this year. The project is his journalistic look at how blood "reveals us, divides us, and unites us." Hill opens the book with a requisite stop at the laboratory bench, where he examines the biological work blood does carrying oxygen, glucose, hormones, cholesterol, Plasmodium parasites, substances of abuse and the "cadaverous particles" responsible for puerperal fever - all powered by the heart (and the iambic metre that mirrors its reassuring lub-DUB, lub-DUB, lub-DUB). From there, Hill steps back for the long view, and that's where things get interesting.

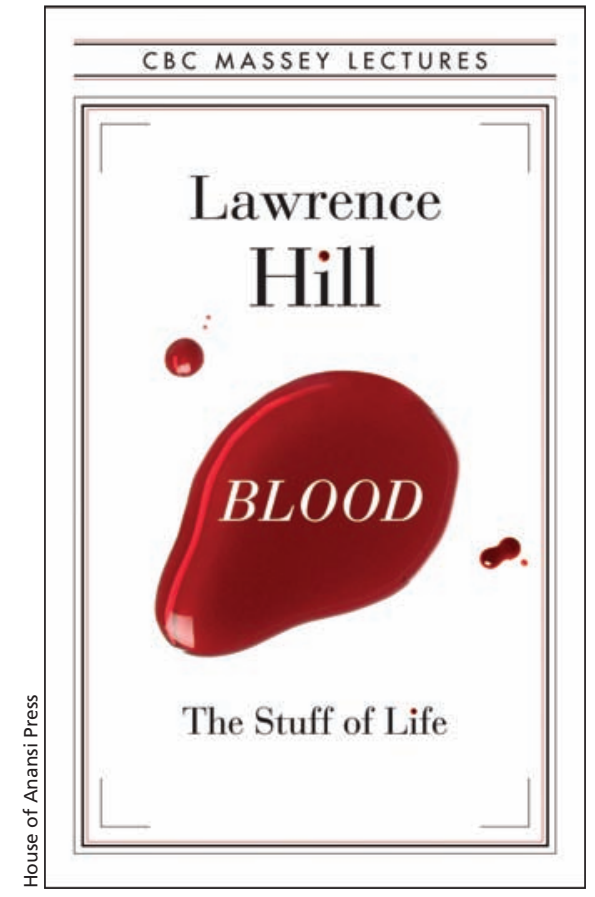

Revolution and the Spanish Inquisition. He uses blood as a metaphor for how virtue and identity - intelligence, creativity, race, religion and the right to rule - run (or do not run) in families. He examines the tenacity of bloodstains (in life and in literature - poor old Lady Macbeth). He unearths blackmarket organ brokers and blood farmers in Nepal. He discusses transracial adoption and the difficulties of crossing international borders with children whose skin does not resemble that of their parents. He examines the place of blood in the works of Shakespeare and

\section{Lawrence Hill traces long rivers of blood through hockey, dogfights, bullfights, boxing, fox hunting, the French Revolution and the Spanish Inquisition.}

Hill casts blood as a kind of Lady Justice in the fall from grace by sporting demigods Lance Armstrong and Ben Johnson. He traces long rivers of blood through hockey, dogfights, bullfights, boxing, fox hunting, the French
Nietzsche. Dexter does not appear, although I suspect Hill would be intrigued by my patient's association of the tools of childbirth with the tools of murder, both blood-soaked domains.

Perhaps readers familiar with Hill's previous works, such as the Commonwealth Writer's Prize-winning The Book of Negroes, or Hill's own identification as the son of a black man and white woman, will not be surprised to know that where Blood really catches flight is at the intersection of medicine and race.

Take, for instance, the story of blood segregation. Who knew that as late as the mid-20th century, "white" blood in America was segregated from "black" blood? Not me. Hill enlightens us with the story of Charles Richard Drew, a black man born in Washington, DC in 1904. Drew went to medical school at McGill in Montréal, Quebec, completing a Master of Surgery degree, only to return to the United States to be told by Allen Whipple (of the eponymous surgical procedure for pancreatic cancer) that he was not of the right hue to treat "a Morgan, an Astor, a Vanderbilt or a Harkness." Drew persisted, however, eventually training under Whipple and going on to become an expert in blood storage. When, in the midst of WWII, the Red Cross announced it would exclude black people from donating blood (a position from which it subsequently backed down, deciding to allow "coloured" people to donate under the condition that their blood be processed separately and given only to other black people), Drew emerged as an outspoken critic. He declared, "One can say quite truthfully that on the battlefields nobody is very interested in where the plasma comes from when they are hurt. ... It is unfortunate that such a worthwhile and scientific bit of work should have been hampered by such stupidity."

Drew's opinions - which mattered hugely, as he was the organization's former medical director - were seconded by white doctors. Cardiologist Bernard Lown (inventor of the defibrillator), then a medical student at Johns Hopkins University in Baltimore, Maryland, is reputed to have taken great delight in mixing up the tags on "coloured" and "white" blood, even being temporarily expelled for giving "coloured" blood to a white patient from Georgia who had 
insisted he not be given any "nigger blood." We scoff at this now, but consider how future generations may view prohibitions on blood donation by men who have sex with men, another topic Hill explores at length. Hill offers special insight into blood and otherness when he relates his experience travelling in the Republic of Niger. Drawn there as a young man wanting to know more about his ancestry, Hill became ill enough to require a blood transfusion. Lying in the hospital bed watching the blood drip into his arm might have made him identify even more strongly with his African heritage. Instead, he found he cared little for the identity of the donor and more about the donor's generosity. Hill's perspective as a selfidentified biracial man, and as someone who has received - and reflected upon receiving - a blood transfusion, seems to give him special licence to explore the idea of blood and what it may and may not mean.

I'll admit that I was surprised to find, when I closed the book, that childbirth had not made an appearance. My own practice as a family doctor means that the delivery room is one of the few places where I see the blood of others, so I am surely biased. Although sex plays a leading role throughout the book, and Hill discusses the blood of menstruation and the blood associated with the tearing of the hymen (and even hymen reconstruction surgery), as well as the purported absence of blood in a witch and although he references motherhood on a number of occasions (Hill and his wife have a blended family of five children), childbirth is not discussed. I would venture to put this on a wish list for a second edition of the book, but this omission is the only thing about which I felt a little let down, as every human life begins with the spilling of blood.

In curating these stories, Hill exercises an expansive licence, using blood as a metaphor for genetics and illness, valour and evil; perhaps blood is his metaphor for the human condition in general. He certainly pushes the boundaries for physician readers, who tend to be a literal bunch, especially when it comes to their medical turf. Those who choose to be more lateral than literal, and to follow Hill on his critical journey through the multiple meanings of blood, will be richly rewarded.

\author{
Monica Kidd MD \\ Assistant professor \\ Department of Family Medicine \\ Faculty of Medicine \\ University of Calgary \\ Calgary, Alta.
}

CMAJ 2014. DOI:10.1503/cmaj.131681

\section{POETRY}

\section{Ethopoiesis}

Girl meets boy, $X$ meets $Y$

A panoply of not-so-hapless variables combined and reduced A courtship and then, la petite mort

And her secret collection: a yoke, a mulberry, a sprout, a swelling A year in the universe only nine months

Convolution - ontogeny recapitulating phylogeny

All the soft machinery building a utopia

For unrolling from stardust to Adam

A new assemblage of indivisible particles not created but born

And borne with the constant threat of growing out of place, growing big, growing through

And the senseless randomness of error: You; not you.

Crowned by departure from the anti-Parthenon, perfected in tears Or such is the hope, to be delivered through imperfect origins

Without intercession by chance or by hand or by word

To spend a lifetime avoiding une mort subite

And hope for a good death?

The task of the doctor, as required

To take in the sick

Or bring out the dead.

Daniel James MD MA

Resident, Department of Emergency Medicine

Ottawa Hospital

Ottawa, Ont.

CMAJ 2014. DOI:10.1503/cmaj.131370

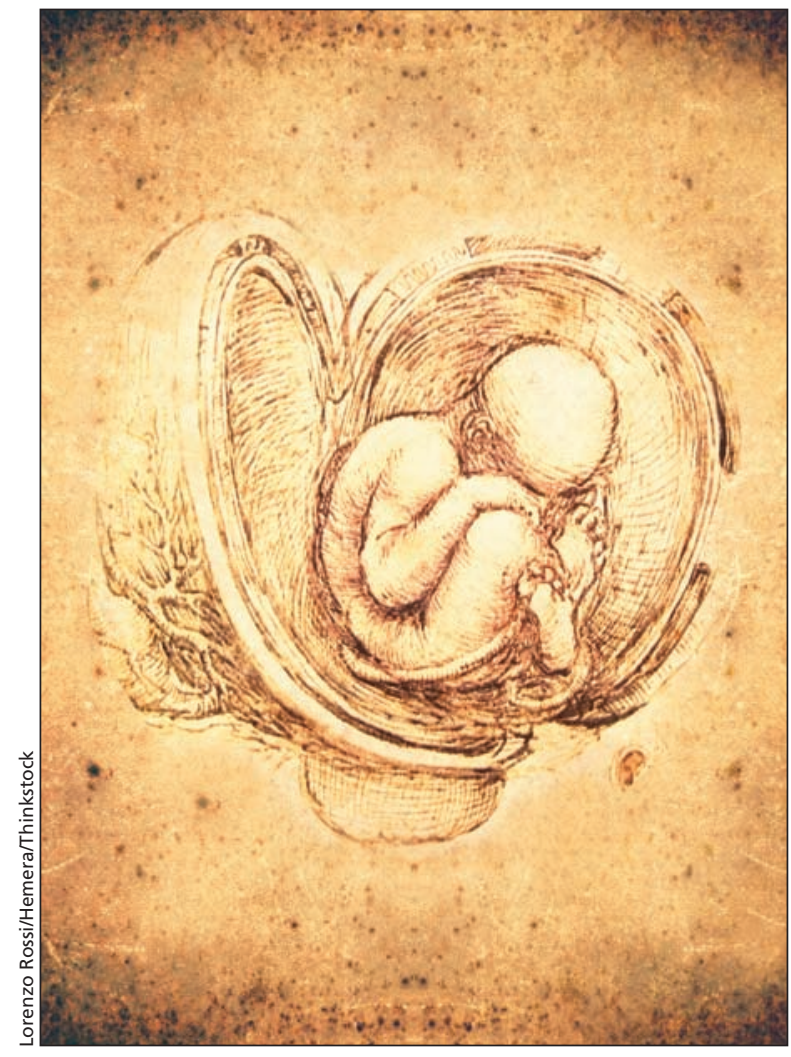

